\title{
Aromatherapy: composition of the gaseous phase at equilibrium with liquid bergamot essential oil
}

\author{
Antonella Leggio', Vanessa Leotta', Emilia Lucia Belsito' ', Maria Luisa Di Gioia', Emanuela Romio', \\ Ilaria Santoro², Domenico Taverna², Giovanni Sindona² and Angelo Liguori ${ }^{*}$
}

\begin{abstract}
This work compares the composition at different temperatures of gaseous phase of bergamot essential oil at equilibrium with the liquid phase. A new GC-MS methodology to determine quantitatively the volatile aroma compounds was developed. The adopted methodology involved the direct injection of headspace gas into injection port of GC-MS system and of known amounts of the corresponding authentic volatile compounds. The methodology was validated. This study showed that gaseous phase composition is different from that of the liquid phase at equilibrium with it.
\end{abstract}

Keywords: Bergamot, Essential oil, Volatile compounds, Gaseous phase, Gas chromatography-mass spectrometry, Aromatherapy

\section{Introduction}

Phytotherapy employs fully characterized active ingredients extracted from plants for the treatment and prevention of many diseases.

Essential oils and their components exhibit various biological activities and are also used for human disease prevention and treatment. They exert antiviral, antidiabetic, antimicrobial and cancer suppressive activities [1,2], furthermore they play a key role in cardiovascular diseases prevention including atherosclerosis and thrombosis [3, 4].

Today aromatherapy, a branch of phytotherapy, is gaining momentum as complementary therapy to the traditional medicine [5]. Aromatherapy uses essential oils via inhalation or massage as the main therapeutic agents to treat several diseases. The inhalation of volatile aromatic substances extracted from plants can affect the mood and state of health of the person by inducing psychological and physical effects [6-10]. The transdermal and

\footnotetext{
*Correspondence: angelo.liguori@unical.it

${ }^{1}$ Dipartimento di Farmacia e Scienze della Salute e della Nutrizione, Università della Calabria, Edificio Polifunzionale, 87036 Arcavacata di Rende, CS, Italy

Full list of author information is available at the end of the article
}

transmucosal application of essential oils also concerns the phytotherapy [11].

Recently, some papers $[12,13]$ have tried to give scientific value to the aromatherapy, traditionally based on empirical observations and evaluations also poorly stringent, by establishing criteria similar to those that support the rigorous scientific research [14]. It has been verified in fact, which among hundreds of papers related to aromatherapy inhalation only a few are scientifically significant [15].

In order to use the essential oil appropriately it is important knowing its chemical compositions and characteristics. It seems clear, however, that if the essential oils are delivered by inhalation, the determination of gas phase (or headspace) composition above the liquid essential oil sample becomes critical $[16,17]$.

The migration of volatile molecules into the headspace phase does not just depend on their volatility but also on their affinity for the liquid phase sample; volatile compounds relative concentrations between the two phases will reach an equilibrium value. At equilibrium, the partial pressure of each volatile component in the headspace vapor will be equivalent to the vapor pressure that is directly proportional to its mole fraction in the liquid 
phase. In essence, the concentration of a compound in the headspace is proportional to its concentration in the liquid phase and can be affected by temperature, respective volumes of the sample and the headspace, and other factors [18]. Thus, headspace phase composition can be very different from that of the liquid phase.

Over the years specific studies designed to identify an analysis procedure for the determination of headspace gas at equilibrium with liquid essential oil have been reported [19-21]. These works are mostly based on the use of solid-phase microextraction (SPME) by which the headspace gas is extracted by a fused silica fiber coated with a suitable stationary phase (HS-SPME) [19, 20]. The volatile compounds adsorbed on the fiber are then thermally desorbed in the GC injector port of a GC-MS instrument to perform the qualitative analysis and GC-FID for the quantitative determination [22].

However, the composition of volatile compounds adsorbed on the fiber is different from that of headspace gas in equilibrium with the essential oil since the adsorption on the fiber depends on the fiber characteristics and extraction conditions used for the analysis. Therefore, this procedure is not sufficient to define the actual composition of the vapor phase in equilibrium with the essential oil, and hence poorly applicable to the study of aromatherapy.

Bergamot (Citrus bergamia) is an endemic plant of the Calabria region in the south of Italy and its fruit is used for the extraction of bergamot essential oil (BEO). Bergamot essential oil is the basic component of perfumes and is also used in the formulation of cosmetic products, food and confections as a flavouring.

The therapeutical applications of Bergamot essential oil are related to its antiseptic, antibacterial and antiinflammatory properties. Of particular interest is also the composition of bergamot juice and albedo because of the presence of molecules with important biological and pharmacological activities [23-26]. Furthermore, it is employed in aromatherapy as an antidepressant to reduce anxiety and stress by improving mood and facilitating sleep induction [27-33].

The determination of headspace composition in bergamot essential oil is extremely useful in aromatherapy. Nevertheless, greater efforts are still needed to develop a simple and objective methodology.

In the present work, we studied the composition of the gaseous phase at equilibrium with the liquid phase of bergamot essential oil by developing a gas chromatography-mass spectrometry (GC-MS) method useful for the determination of the volatile aroma components.

\section{Experimental \\ Materials}

Bergamot essential oil (Citrus bergamia Risso et Poiteau) was supplied by the "Consorzio del Bergamotto di Reggio Calabria” (Southern Italy).

\section{Chemicals and reagents}

$\alpha$-Pinene, $\alpha$-fellandrene, $\alpha$-terpinene, linalyl acetate, neral, geranial were purchased from Sigma-Aldrich Co. (Italy). $\beta$-Pinene, $p$-cimene, $\gamma$-terpinene, terpinolene, linalool, $\alpha$-terpineol were purchased from Fluka. Mircene, ocimene, neryl acetate, octyl acetate, $\beta$-caryophyllene and limonene were purchased from Merck KGaA. Anisole was purchased from Sigma-Aldrich Co (Italy) and used as internal standard.

\section{GC-MS analysis}

GC-MS analyses were performed using a $6890 \mathrm{~N}$ Network GC System (Agilent Technologies Inc., Palo Alto, CA) equipped with a HP-35MS (35\% diphenylsiloxane; $\mathrm{l}=20 \mathrm{~m}, \mathrm{~d}=0.25 \mathrm{~mm} 0.25 \mu \mathrm{m}$ ) capillary column and with a mass spectrometer 5973 Network MSD operated in electron impact ionization mode $(70 \mathrm{eV})$. GC-MS analyses were carried out in split mode, using helium as the carrier gas $(1 \mathrm{~mL} / \mathrm{min}$ flow rate). The column was maintained at an initial temperature of $40{ }^{\circ} \mathrm{C}$ for $0 \mathrm{~min}$, then ramped to $250^{\circ} \mathrm{C}$ at $3{ }^{\circ} \mathrm{C} / \mathrm{min}$, to $280^{\circ} \mathrm{C}$ at $5^{\circ} \mathrm{C} / \mathrm{min}$, where it was maintained for $15 \mathrm{~min}$. Quantitative GCMS analysis was carried out in splitless mode (splitless time, $1 \mathrm{~min}$ ), by using anisole as the internal standard. The identification of the compounds was based on comparison of their retention times with those of authentic samples, and on comparison of their EI-mass spectra with the NIST/NBS, Wiley library spectra and literature [26].

\section{GC-FID analysis}

GC-MS analyses were performed using a HP6890 A series 2 GC System (Agilent Technologies Inc., Palo Alto, CA) equipped with a HP-35MS (35\% diphenylsiloxane; $\mathrm{I}=20 \mathrm{~m}, \mathrm{~d}=0.25 \mathrm{~mm} 0.25 \mu \mathrm{m})$. The column temperature was programmed at $40{ }^{\circ} \mathrm{C}$ for $0 \mathrm{~min}$, to $250{ }^{\circ} \mathrm{C}$ at $3{ }^{\circ} \mathrm{C} / \mathrm{min}$, to $280{ }^{\circ} \mathrm{C}$ at $5{ }^{\circ} \mathrm{C} / \mathrm{min}$, where it was maintained for $15 \mathrm{~min}$. The injector and detector temperatures were programmed at 230 and $300{ }^{\circ} \mathrm{C}$, respectively. Helium was used as the carrier gas at a flow rate $1 \mathrm{~mL} / \mathrm{min}$. 


\begin{tabular}{|c|c|c|}
\hline \multicolumn{2}{|c|}{$\begin{array}{l}\text { Stock solutions F } \\
\text { a-Pinene; } p \text {-cimene; mircene; linalool }\end{array}$} & $\begin{array}{l}\text { Concentration for each } \\
\text { analyte } \\
(\mathrm{mg} / \mathrm{mL})\end{array}$ \\
\hline \multicolumn{2}{|l|}{ Solution 1} & 0.015 \\
\hline \multicolumn{2}{|l|}{ Solution 2} & 0.025 \\
\hline \multicolumn{2}{|l|}{ Solution 3} & 0.050 \\
\hline \multicolumn{2}{|l|}{ Solution 4} & 0.065 \\
\hline \multicolumn{2}{|l|}{ Solution 5} & 0.075 \\
\hline \multicolumn{2}{|l|}{ Solution 6} & 0.085 \\
\hline $\begin{array}{l}\text { Stock solutions } \mathrm{H} \\
\text { Limonene; } \beta \text {-pinene }\end{array}$ & \multicolumn{2}{|c|}{$\begin{array}{l}\text { Concentration for each analyte } \\
(\mathrm{mg} / \mathrm{mL})\end{array}$} \\
\hline Solution 1 & \multicolumn{2}{|c|}{0.225} \\
\hline Solution 2 & \multicolumn{2}{|l|}{0.30} \\
\hline Solution 3 & \multicolumn{2}{|c|}{0.375} \\
\hline Solution 4 & \multicolumn{2}{|c|}{0.450} \\
\hline Solution 5 & \multicolumn{2}{|c|}{0.525} \\
\hline Solution 6 & \multicolumn{2}{|l|}{0.60} \\
\hline
\end{tabular}

\section{Quantitative analysis of bergamot essential oil Sample preparation}

Three aliquots of the essential oil bergamot (55, 95 and $147 \mathrm{mg})$, containing anisole $(0.1 \mathrm{~mL})$ as internal standard, were diluted to $5 \mathrm{~mL}$ with diethyl ether and then subjected to the quantitative analysis. Quantitative data were obtained by comparing the analyte/anisole area ratios in the standard solutions with the corresponding ratios in the oil samples solutions.

\section{Internal standard solution}

$40 \mathrm{mg}$ of anisole were diluted to $100 \mathrm{~mL}$ with diethyl ether.

\section{Preparation of stock solutions $A-D$}

For the quantitative analysis of $\beta$-pinene limonene, $\gamma$-terpinene, linalool, linalyl acetate, five stock solutions A were prepared using $150 \mathrm{mg}$ of each analytes and dissolving them in $5 \mathrm{~mL}$ of diethyl ether. Solutions A were further used to prepare diluted working solutions B. In particular, $0.1,0.2,0.5,1,1.3$ and $1.5 \mathrm{~mL}$ of each stock solution $\mathrm{A}$, after adding $0.1 \mathrm{~mL}$ of the internal standard solution, was made up to $5 \mathrm{~mL}$ volume with diethyl ether. The final concentrations of each analyte in working solutions $B$ were $0.6,1.2,3,6,7.8,9.6 \mathrm{mg} / \mathrm{mL}$ respectively.

For the quantitative analysis of $\alpha$-pinene, $\alpha$-phellandrene, $\alpha$-terpinene, $\mathrm{p}$-cimene, terpinolene, myrcene, ocimene, neral, geranial, neryl acetate, $\alpha$-terpineol, octyl acetate, caryophyllene, thirteen stock solutions $C$ were prepared as follows: $50 \mathrm{mg}$ of each analyte was diluted to $100 \mathrm{~mL}$ with diethyl ether. Aliquots of these solutions $\mathrm{C}$ were then used to prepare diluted working solutions D. In particular, 0.2, 0.5, 1, 1.3, 1.7 and $2.5 \mathrm{~mL}$ of each analyte, after adding $0.1 \mathrm{~mL}$ of the internal standard solution, was made up to $5 \mathrm{~mL}$ volume with diethyl ether. The final concentrations of each analyte in working solutions D were 0.02, 0.05, 0.10, 0.13, $0.17,0.21 \mathrm{mg} / \mathrm{mL}$.

\section{Quantitative analysis of the gaseous phase of bergamot essential oil Sample preparation}

Three samples of the gaseous phase of the bergamot essential oil were prepared as follows: $100 \mathrm{mg}$ of bergamot essential oil and $7 \mathrm{mg}$ of anisole used as the internal standard, were transferred to three $10 \mathrm{~mL}$ vials that were sealed and then maintained at 0,22 and $40{ }^{\circ} \mathrm{C}$ respectively.

The temperature of $0{ }^{\circ} \mathrm{C}$ was obtained using an ice bath in which liquid phase and solid phase coexist. The temperature of $22{ }^{\circ} \mathrm{C}$ was that measured in a conditioned environment at $22{ }^{\circ} \mathrm{C} .40{ }^{\circ} \mathrm{C}$ was obtained by means of a thermostated oil bath with a digital vertex thermometer.

After 30 min, a gastight syringe was used to weigh out the gaseous phase $(0.4 \mathrm{~mL})$ and then subjected to the quantitative analysis by both GC-MS and GC-FID. Quantitative data were obtained by comparing the analyte/anisole area ratios in the standard solutions with the corresponding ratios in the essential oil samples solutions.

\section{Internal standard solution}

$20 \mathrm{mg}$ of anisole was diluted to $500 \mathrm{~mL}$ with diethyl ether.

Preparation of stock solutions for the quantitative analysis at $0^{\circ} \mathrm{C}$ (Table 1 )

Preparation of stock solutions $E-H$

For the quantitative analysis of $\alpha$-pinene, $p$-cimene, mircene, linalool, linalyl acetate at $0{ }^{\circ} \mathrm{C}$, five stock solutions $\mathrm{E}$ were prepared using $50 \mathrm{mg}$ of each analytes and dissolving them in $100 \mathrm{~mL}$ of diethyl ether. Solutions $\mathrm{E}$ were further used to prepare diluted working solutions F. In particular, $0.3,0.5,1,1.3,1.5,1.7 \mathrm{~mL}$ of each stock solution $\mathrm{E}$, after adding $0.1 \mathrm{~mL}$ of the internal standard solution, was made up to $10 \mathrm{~mL}$ volume with diethyl ether. The final concentrations of each analyte in working solutions $F$ were $0.015,0.025,0.050,0.065,0.075$ and $0.085 \mathrm{mg} / \mathrm{mL}$ respectively.

For the quantitative analysis of limonene and $\beta$-pinene at $0{ }^{\circ} \mathrm{C}$, two stock solutions $\mathrm{G}$ were prepared using $150 \mathrm{mg}$ of each analytes and dissolving them in $100 \mathrm{~mL}$ of diethyl ether. Solutions G were further used to prepare diluted working solutions $\mathrm{H}$. In particular, 1.5, 
Table 2 Stock solutions for the quantitative analysis at 22 and $40^{\circ} \mathrm{C}$

\begin{tabular}{|c|c|c|c|c|c|c|}
\hline \multicolumn{3}{|c|}{ Quantitative analysis at $22^{\circ} \mathrm{C}$} & \multicolumn{4}{|c|}{ Quantitative analysis at $40^{\circ} \mathrm{C}$} \\
\hline \multirow{2}{*}{$\begin{array}{l}\text { Stock solutions J } \\
\text { a-Phellandrene; } \\
\text { a-terpinene; } \\
\text { p-cimene; } \\
\text { mircene; linalyl } \\
\text { acetate } \\
\text { Solution } 1\end{array}$} & \multicolumn{2}{|c|}{$\begin{array}{l}\text { Concentration or each ana- } \\
\text { lyte }(\mathrm{mg} / \mathrm{mL})\end{array}$} & \multicolumn{2}{|c|}{$\begin{array}{l}\text { Stock solutions } P \\
\text { a-Terpinene; } p \text {-cimene; mircene; }\end{array}$} & \multicolumn{2}{|c|}{ Concentration for each analyte $(\mathrm{mg} / \mathrm{mL})$} \\
\hline & \multicolumn{2}{|l|}{0.002} & \multicolumn{2}{|l|}{ Solution 1} & \multicolumn{2}{|l|}{0.001} \\
\hline Solution 2 & \multicolumn{2}{|l|}{0.004} & \multicolumn{2}{|l|}{ Solution 2} & \multicolumn{2}{|l|}{0.002} \\
\hline Solution 3 & \multicolumn{2}{|l|}{0.006} & \multicolumn{2}{|l|}{ Solution 3} & \multicolumn{2}{|l|}{0.004} \\
\hline Solution 4 & \multicolumn{2}{|l|}{0.008} & \multicolumn{2}{|l|}{ Solution 4} & \multicolumn{2}{|l|}{0.006} \\
\hline Solution 5 & \multicolumn{2}{|l|}{0.010} & \multicolumn{2}{|l|}{ Solution 5} & \multicolumn{2}{|l|}{0.008} \\
\hline Solution 6 & \multicolumn{2}{|l|}{0.015} & Solution 6 & & \multicolumn{2}{|l|}{0.010} \\
\hline \multicolumn{4}{|c|}{ Quantitative analysis at $22^{\circ} \mathrm{C}$} & \multicolumn{3}{|c|}{ Quantitative analysis at $40^{\circ} \mathrm{C}$} \\
\hline \multicolumn{2}{|c|}{$\begin{array}{l}\text { Stock solutions } L \\
\text { a-Pinene; } Y \text {-terpinene; linalool }\end{array}$} & \multicolumn{2}{|c|}{$\begin{array}{l}\text { Concentration for each analyte } \\
(\mathrm{mg} / \mathrm{mL})\end{array}$} & \multicolumn{2}{|c|}{$\begin{array}{l}\text { Stock solutions } \mathrm{R} \\
\text { Octyl acetate; a-phellandrene; } \\
\text { a-pinene }\end{array}$} & $\begin{array}{l}\text { Concentration for each analyte } \\
(\mathrm{mg} / \mathrm{mL})\end{array}$ \\
\hline \multicolumn{2}{|l|}{ Solution 1} & \multicolumn{2}{|l|}{0.050} & \multicolumn{2}{|l|}{ Solution 1} & 0.010 \\
\hline \multicolumn{2}{|l|}{ Solution 2} & \multicolumn{2}{|l|}{0.065} & \multicolumn{2}{|l|}{ Solution 2} & 0.015 \\
\hline Solution 3 & & 0.085 & & Solution 3 & & 0.020 \\
\hline Solution 4 & & 0.10 & & Solution 4 & & 0.025 \\
\hline Solution 5 & & 0.120 & & Solution 5 & & 0.030 \\
\hline Solution 6 & & 0.140 & & Solution 6 & & 0.035 \\
\hline Quantitative anal & sis at $22^{\circ} \mathrm{C}$ & & & Quantitative & $40^{\circ} \mathrm{C}$ & \\
\hline $\begin{array}{l}\text { Stock solutions } N \\
\text { Limonene; } \beta \text {-pine }\end{array}$ & & $\begin{array}{l}\text { Concentratio } \\
(\mathrm{mg} / \mathrm{mL})\end{array}$ & for each analyte & $\begin{array}{l}\text { Stock solutior } \\
\text { Limonene; } \beta-1 \\
\text { acetate; } \gamma \text {-ter }\end{array}$ & $\begin{array}{l}\text { alyl } \\
\text { alool }\end{array}$ & $\begin{array}{l}\text { Concentration for each analyte } \\
(\mathrm{mg} / \mathrm{mL})\end{array}$ \\
\hline Solution 1 & & 0.10 & & Solution 1 & & 0.070 \\
\hline Solution 2 & & 0.20 & & Solution 2 & & 0.150 \\
\hline Solution 3 & & 0.30 & & Solution 3 & & 0.20 \\
\hline Solution 4 & & 0.40 & & Solution 4 & & 0.250 \\
\hline Solution 5 & & 0.50 & & Solution 5 & & 0.30 \\
\hline Solution 6 & & 0.60 & & Solution 6 & & 0.350 \\
\hline
\end{tabular}

2, 2.5, 3, 3.5 and $4 \mathrm{~mL}$ of each stock solution G, after adding $0.1 \mathrm{~mL}$ of the internal standard solution, was made up to $10 \mathrm{~mL}$ volume with diethyl ether. The final concentration of each analyte in working solutions $\mathrm{H}$ were $0.225,0.30,0.375,0.450,0.525$ and $0.60 \mathrm{mg} / \mathrm{mL}$ respectively.

\section{Preparation of stock solutions for the quantitative analysis at $22^{\circ} \mathrm{C}$ (Table 2) \\ Preparation of stock solutions $\mathrm{I}-\mathrm{N}$}

For the quantitative analysis of $\alpha$-phellandrene, $\alpha$-terpinene, $p$-cimene, mircene, linalyl acetate at $22{ }^{\circ} \mathrm{C}$, five stock solutions I were prepared using $10 \mathrm{mg}$ of each analytes and dissolving them in $100 \mathrm{~mL}$ of diethyl ether. Solutions I were further used to prepare diluted working solutions J. In particular, 0.2, 0.4, 0.6, 0.8, 1.0, $1.5 \mathrm{~mL}$ of each stock solution $\mathrm{I}$, after adding $0.1 \mathrm{~mL}$ of the internal standard solution, was made up to $10 \mathrm{~mL}$ volume with diethyl ether. The final concentrations of each analyte in working solutions J were $0.002,0.004,0.006,0.008,0.010$ and $0.015 \mathrm{mg} / \mathrm{mL}$ respectively.

For the quantitative analysis of $\alpha$-pinene, $\gamma$-terpinene and linalool at $22{ }^{\circ} \mathrm{C}$, three stock solutions $\mathrm{K}$ were prepared using $50 \mathrm{mg}$ of each analytes and dissolving them in $100 \mathrm{~mL}$ of diethyl ether. Solutions $\mathrm{K}$ were further used to prepare diluted working solutions $\mathrm{L}$. In particular, 1.0, 
1.3, 1.7, 2.0, 2.4, $2.8 \mathrm{~mL}$ of each stock solution $\mathrm{K}$, after adding $0.1 \mathrm{~mL}$ of the internal standard solution, was made up to $10 \mathrm{~mL}$ volume with diethyl ether. The final concentrations of each analyte in working solutions $\mathrm{L}$ were 0.05 , $0.065,0.085,0.10,0.12,0.14 \mathrm{mg} / \mathrm{mL}$ respectively. For the quantitative analysis of limonene and $\beta$-pinene at $22{ }^{\circ} \mathrm{C}$, two stock solutions $\mathrm{M}$ were prepared using $100 \mathrm{mg}$ of each analytes and dissolving them in $100 \mathrm{~mL}$ of diethyl ether. Solutions $\mathrm{M}$ were further used to prepare diluted working solutions N. In particular, 1.0, 2.0, 3.0, 4.0, 5.0 and $6.0 \mathrm{~mL}$ of each stock solution $\mathrm{M}$, after adding $0.1 \mathrm{~mL}$ of the internal standard solution, was made up to $10 \mathrm{~mL}$ volume with diethyl ether. The final concentrations of each analyte in working solutions $\mathrm{N}$ were $0.10,0.20,0.30$, $0.40,0.50$ and $0.60 \mathrm{mg} / \mathrm{mL}$ respectively.

\section{Preparation of stock solutions for the quantitative analysis} at $40{ }^{\circ} \mathrm{C}$ (Table 2)

\section{Preparation of stock solutions O-T}

For the quantitative analysis of $\alpha$-terpinene, $p$-cimene and mircene, at $40{ }^{\circ} \mathrm{C}$, three stock solutions $\mathrm{O}$ were prepared using $10 \mathrm{mg}$ of each analytes and dissolving them in $100 \mathrm{~mL}$ of diethyl ether. Solutions $\mathrm{O}$ were further used to prepare diluted working solutions P. In particular, 0.1, $0.2,0.4,0.6,0.8,1.0 \mathrm{~mL}$ of each stock solution $\mathrm{O}$, after adding $0.1 \mathrm{~mL}$ of the internal standard solution, was made up to $10 \mathrm{~mL}$ volume with diethyl ether. The final concentrations of each analyte in working solutions $\mathrm{P}$ were $0.001,0.002,0.004,0.006,0.008$ and $0.01 \mathrm{mg} / \mathrm{mL}$ respectively. For the quantitative analysis of $\alpha$-pinene, $\alpha$-phellandrene and octylacetate, at $40{ }^{\circ} \mathrm{C}$, two stock solutions $\mathrm{Q}$ were prepared using $10 \mathrm{mg}$ of each analytes and dissolving them in $100 \mathrm{~mL}$ of diethyl ether. Solutions Q were further used to prepare diluted working solutions $\mathrm{R}$. In particular, 1.0, 1.5, 2.0, 2.5, 3.0, $3.5 \mathrm{~mL}$ of each stock solution $\mathrm{Q}$, after adding $0.1 \mathrm{~mL}$ of the internal standard solution, was made up to $10 \mathrm{~mL}$ volume with diethyl ether. The final concentrations of each analyte in working solutions $\mathrm{R}$ were $0.010,0.015,0.020,0.025,0.030$, $0.035 \mathrm{mg} / \mathrm{mL}$ respectively. For the quantitative analysis of limonene, $\beta$-pinene, linalyl acetate, $\gamma$-terpinene and linalool at $40{ }^{\circ} \mathrm{C}$, five stock solutions $\mathrm{S}$ were prepared using $100 \mathrm{mg}$ of each analytes and dissolving them in $100 \mathrm{~mL}$ of diethyl ether. Solutions S were further used to prepare diluted working solutions $\mathrm{T}$. In particular, $0.7,1.5,2.0$, 2.5, 3.0 and $3.5 \mathrm{~mL}$ of each stock solution $\mathrm{S}$, after adding $0.1 \mathrm{~mL}$ of the internal standard solution, was made up to $10 \mathrm{~mL}$ volume with diethyl ether. The final concentrations of each analyte in working solutions $\mathrm{T}$ were 0.07 , $0.15,0.20,0.25,0.30$ and $0.35 \mathrm{mg} / \mathrm{mL}$ respectively.

\section{Statistical analysis}

Statistical analyses were carried out with the SPSS Statistics 23.0 (SPSS Inc., Chicago, IL, USA). For each compound, six solutions were prepared and analyzed by GC-MS. The statistical analysis was obtained comparing the analyte/anisole area ratios in the solutions with the corresponding concentrations. A value of $\mathrm{P}$ correspondent to 0.011 was considered significant.

\section{Results and discussion}

The distilled bergamot essential oil used was preliminarily analyzed to define its composition. The individual analytes present in the oil were identified by GC-MS 
Table 3 Composition of $\mathrm{BEO}$ and gaseous phase in equilibrium with the liquid at $0{ }^{\circ} \mathrm{C}$

\begin{tabular}{|c|c|c|c|c|c|c|}
\hline \multirow[t]{2}{*}{ Entry } & \multirow[t]{2}{*}{ Compound } & \multicolumn{2}{|c|}{ Essential oil composition ${ }^{a}$} & \multicolumn{3}{|c|}{ Gaseous phase composition at $0^{\circ} \mathrm{C}$} \\
\hline & & $\begin{array}{l}t_{R}(G C / M S) \\
(\min )\end{array}$ & $\begin{array}{l}\text { GC-MS } \\
(w / w \% \pm S D)\end{array}$ & $\begin{array}{l}\text { GC-MS } \\
(w / w \% \pm S D)\end{array}$ & $\begin{array}{l}\text { GC-FID } \\
(w / w \% \pm \text { SD) }\end{array}$ & $\begin{array}{l}t_{R}(G C / F I D) \\
(\min )\end{array}$ \\
\hline \multicolumn{7}{|c|}{ Cyclic hydrocarbon monoterpenes } \\
\hline 1 & a-Pinene & 6.14 & $1.03 \pm 0.10$ & $6.90 \pm 0.10$ & $7.06 \pm 0.25$ & 6.14 \\
\hline 2 & $\beta$-Pinene & 8.19 & $6.56 \pm 0.14$ & $25.90 \pm 0.40$ & $26.68 \pm 0.15$ & 8.31 \\
\hline 3 & a-Phellandrene & 9.48 & $0.04 \pm 0.01$ & - & - & - \\
\hline 4 & a-Terpinene & 9.94 & $0.16 \pm 0.02$ & - & - & - \\
\hline 5 & Limonene & 10.60 & $30.20 \pm 0.77$ & $58.07 \pm 0.38$ & $57.12 \pm 0.35$ & 10.48 \\
\hline 6 & p-Cimene & 11.19 & $0.18 \pm 0.01$ & $6.36 \pm 0.04$ & $6.02 \pm 0.08$ & 11.61 \\
\hline 7 & Y-Terpinene & 12.15 & $11.95 \pm 0.32$ & - & - & - \\
\hline 8 & Terpinolene & 13.36 & $0.27 \pm 0.03$ & - & - & - \\
\hline \multicolumn{7}{|c|}{ Acyclic hydrocarbon monoterpenes } \\
\hline 9 & Mircene & 8.72 & $0.82 \pm 0.02$ & $2.19 \pm 0.22$ & $2.16 \pm 0.15$ & 8.49 \\
\hline 10 & Ocimene & 11.03 & $0.08 \pm 0.01$ & - & - & - \\
\hline \multicolumn{7}{|c|}{ Acyclic oxygenated hydrocarbon monoterpenes } \\
\hline 11 & Linalool & 14.58 & $21.82 \pm 0.87$ & $3.04 \pm 0.54$ & $2.96 \pm 0.33$ & 14.55 \\
\hline 12 & Linalyl acetate & 21.42 & $16.21 \pm 0.84$ & - & - & - \\
\hline 13 & Neral & 22.94 & $0.21 \pm 0.01$ & - & - & - \\
\hline 14 & Geranial & 24.46 & $0.11 \pm 0.01$ & - & - & - \\
\hline 15 & Neryl acetate & 28.14 & $0.28 \pm 0.02$ & - & - & - \\
\hline \multicolumn{7}{|c|}{ Cyclic oxygenated hydrocarbon monoterpenes } \\
\hline 16 & a-Terpineol & 20.01 & $0.87 \pm 0.08$ & - & - & - \\
\hline \multicolumn{7}{|l|}{ Esters } \\
\hline 17 & Octyl acetate & 19.63 & $0.10 \pm 0.01$ & - & - & - \\
\hline \multicolumn{7}{|c|}{ Sesquiterpenes } \\
\hline 18 & $\beta$-Caryophyllene & 27.85 & $0.14 \pm 0.02$ & - & - & - \\
\hline
\end{tabular}

SD standard deviations

${ }^{a}$ The $\mathrm{w} / \mathrm{w}$ percentages were determined by the internal standard method and referred to the amount of each component contained in $100 \mathrm{~g}$ of essential oil

methodology by comparing the corresponding retention times and mass spectra with those of authentic sample (Table 3).

Anisole was chosen as internal standard for the quantitative measurement of the individual analytes.

For the quantitative analysis, six standard stock solution (Stock B and Stock C) containing different concentration levels of each identified analyte and the same amount of internal standard were prepared.

Each solution was injected in triplicate in the GC-MS system under optimized conditions. For each measurement, the concentration and the peak area of the analytes were compared with those of the internal standard.

Table 1 reports the quantitative results only for the identified analytes.

High contents of limonene, linalool, linalyl acetate, and $\alpha$-terpinene are observed in analogy with the data reported in literature $[18,33,34]$.
The determination of gas phase composition above the liquid oil has preliminarily required controlled temperature and pre-established equilibrium conditions.

To this aim, a weighed amount of essential oil was placed in a headspace vial, after adding a given amount of anisole the vial was sealed and then allowed to stand for $30 \mathrm{~min}$ at $0{ }^{\circ} \mathrm{C}$ to establish the equilibrium at that temperature. Once the volatile compounds have equilibrated, an aliquot of the headspace gas was withdrawn using a gas tight syringe, injected into the gas chromatograph injection port and analyzed by GC-MS. The individual analytes present in the headspace gas were identified through comparison of retention times and mass spectral data with those of authentic standards (Fig. 1).

Additional experiments using equilibration times longer than $30 \mathrm{~min}$ were also carried out. After $60 \mathrm{~min}$ equilibration time the relative ratios between the 
different volatile components did not change significantly compared to those obtained after $30 \mathrm{~min}$.

For the quantitative analysis, seven stock solutions containing the reference analytes at known concentrations and a given amount of anisole as internal standard were used. An aliquot $(1 \mu \mathrm{L})$ of each of these stock solutions (Stock F and Stock $\mathrm{H}$ ) was injected into the GCMS injection port where it was completely turned to gas and analyzed. All the analyses were performed in splitless conditions in triplicate.

The determination of each analyte concentration level in the headspace gas of essential oil sample was performed by comparing the peak area of each individual headspace analyte with the corresponding peak area in the reference solutions, the peak area of the analytes are always compared with those of the internal standard.

The adopted methodology assumes that the total sample amount introduced into the injection port is vaporized and that all the produced gas reaches the ion source (splitless conditions).

The quantitative results are listed in Table 3.

In this study, the headspace gas in equilibrium with the bergamot oil sample at $0{ }^{\circ} \mathrm{C}$ has been also investigated by means of GC-FID in order to validate the proposed methodology (Fig. 2).

The results of GC-FID analysis are comparable to those obtained by GC-MS (Table 3). It can be observed that the gaseous phase composition is quite different from that of the liquid phase at equilibrium with it a $0{ }^{\circ} \mathrm{C}$.

The comparison between the bergamot essential oil composition (Table 3) and that of headspace gas at equilibrium shows how the linalool and the linalyl acetate amounts decrease dramatically in the gas phase on the contrary the concentration of limonene is almost double (approximately 60\%).

Furthermore, the $\beta$-pinene content, that is very low in the liquid oil, is particularly high in gaseous phase.

The composition of the gaseous phase at $22{ }^{\circ} \mathrm{C}$ (room temperature) and $40{ }^{\circ} \mathrm{C}$ was determined by using the stock solutions $I-N$ and $O-T$ respectively as described in "Experimental" section. The quantitative results are listed in Table 4.

At $22^{\circ} \mathrm{C}$ the gas phase in equilibrium with liquid phase is enriched in some components with respect to the composition determined at $0{ }^{\circ} \mathrm{C}$. In fact, $\alpha$-phellandrene, $\alpha$-terpinene, $\gamma$-terpinene, linalool and linalyl acetate, which were not detected in the gaseous phase at $0{ }^{\circ} \mathrm{C}$, were identified and determined in the gaseous phase at $22{ }^{\circ} \mathrm{C}$. In particular, at $22{ }^{\circ} \mathrm{C} \gamma$-terpinene and linalyl acetate got to 13.13 and $0.66 \%$ respectively and linalool grew from 3 to $9 \%$ (Table 2). At both temperature, the main components were limonene $\left(58.07 \%\right.$ at $0{ }^{\circ} \mathrm{C}$ and $47.27 \%$ at $22{ }^{\circ} \mathrm{C}$ ) and $\beta$-pinene $\left(25.90 \%\right.$ at $0{ }^{\circ} \mathrm{C}$ and $19.69 \%$ at $22{ }^{\circ} \mathrm{C}$ ).

The composition of the headspace vapor generated at $40{ }^{\circ} \mathrm{C}$ was characterized by the presence of octyl acetate, 
Table 4 Composition of BEO and gaseous phase in equilibrium with the liquid at 0,22 and $40^{\circ} \mathrm{C}$

\begin{tabular}{|c|c|c|c|c|c|c|}
\hline \multirow[t]{2}{*}{ Entry } & \multirow[t]{2}{*}{ Compound } & \multirow{2}{*}{$\begin{array}{l}\text { Essential oil } \\
\text { composition }^{a} \\
\text { GC-MS } \\
\text { (w/w\% } \pm \text { SD) }\end{array}$} & \multirow{2}{*}{$\begin{array}{l}\text { Gaseous phase } \\
\text { composition } \\
\text { at } 0{ }^{\circ} \mathrm{C} \\
\text { GC-MS } \\
(\mathrm{w} / \mathrm{w} \% \pm \mathrm{SD})\end{array}$} & \multirow{2}{*}{$\begin{array}{l}\text { Gaseous phase } \\
\text { composition } \\
\text { at } 22^{\circ} \mathrm{C} \\
\text { GC-MS } \\
(\mathrm{w} / \mathrm{w} \% \pm \mathrm{SD})\end{array}$} & \multirow{2}{*}{$\begin{array}{l}\text { Gaseous phase } \\
\text { composition } \\
\text { at } 40^{\circ} \mathrm{C} \\
\text { GC-MS } \\
(w / w \% \pm S D)\end{array}$} & \multirow[t]{2}{*}{ Biological activity } \\
\hline & & & & & & \\
\hline \multicolumn{7}{|c|}{ Cyclic hydrocarbon monoterpenes } \\
\hline 1 & a-Pinene & $1.03 \pm 0.10$ & $6.90 \pm 0.10$ & $5.38 \pm 0.10$ & $1.29 \pm 0.03$ & $\begin{array}{l}\text { Anticancer [35] } \\
\text { Anti-inflammatory [36] }\end{array}$ \\
\hline 2 & $\beta$-Pinene & $6.56 \pm 0.14$ & $25.90 \pm 0.40$ & $19.69 \pm 0.31$ & $7.10 \pm 0.05$ & $\begin{array}{l}\text { Anti-depressant [37] } \\
\text { Antibacterial [38] }\end{array}$ \\
\hline 3 & a-Phellandrene & $0.04 \pm 0.01$ & - & $0.27 \pm 0.02$ & $0.39 \pm 0.02$ & $\begin{array}{l}\text { Anti-proliferative [39] } \\
\text { Anti-inflammatory [40] }\end{array}$ \\
\hline 4 & a-Terpinene & $0.16 \pm 0.02$ & - & $0.27 \pm 0.01$ & $0.18 \pm 0.02$ & Antioxidant [41] \\
\hline 5 & Limonene & $30.20 \pm 0.77$ & $58.07 \pm 0.38$ & $47.27 \pm 0.28$ & $37.15 \pm 0.29$ & $\begin{array}{l}\text { Anti-inflammatory }[42 \text {, } \\
43] \\
\text { Anxiolytic }[44] \\
\text { Anti-proliferative }[45,46]\end{array}$ \\
\hline 6 & p-Cimene & $0.18 \pm 0.01$ & $6.36 \pm 0.04$ & $0.62 \pm 0.03$ & $0.49 \pm 0.01$ & $\begin{array}{l}\text { Anti-inflammatory [47] } \\
\text { Antifungal [48] }\end{array}$ \\
\hline 7 & Y-Terpinene & $11.95 \pm 0.32$ & - & $13.13 \pm 0.29$ & $12.22 \pm 0.1$ & $\begin{array}{l}\text { Antibacterial [49] } \\
\text { Antioxidant [49] }\end{array}$ \\
\hline 8 & Terpinolene & $0.27 \pm 0.03$ & - & - & - & \\
\hline \multicolumn{7}{|c|}{ Acyclic hydrocarbon monoterpenes } \\
\hline 9 & Mircene & $0.82 \pm 0.02$ & $2.19 \pm 0.22$ & $1.42 \pm 0.036$ & $0.84 \pm 0.02$ & $\begin{array}{l}\text { Analgesic [50] } \\
\text { Anxiolytic [51, 52] }\end{array}$ \\
\hline 10 & Ocimene & $0.08 \pm 0.01$ & - & - & - & \\
\hline \multicolumn{7}{|c|}{ Acyclic oxygenated hydrocarbon monoterpenes } \\
\hline 11 & Linalool & $21.82 \pm 0.87$ & $3.04 \pm 0.54$ & $9.71 \pm 0.18$ & $27.52 \pm 0.24$ & $\begin{array}{l}\text { Anti-inflammatory [53, } \\
54] \\
\text { Anti-epileptic [55] } \\
\text { Anxiolytic [56] }\end{array}$ \\
\hline 12 & Linalyl acetate & $16.21 \pm 0.84$ & - & $0.66 \pm 0.03$ & $10.40 \pm 0.08$ & $\begin{array}{l}\text { Anti-inflammatory [57] } \\
\text { Analgesic [57] } \\
\text { Antibacterial [58] }\end{array}$ \\
\hline 13 & Neral & $0.21 \pm 0.01$ & - & - & - & \\
\hline 14 & Geranial & $0.11 \pm 0.01$ & - & - & - & \\
\hline 15 & Neryl acetate & $0.28 \pm 0.02$ & - & - & - & \\
\hline \multicolumn{7}{|c|}{ Cyclic oxygenated hydrocarbon monoterpenes } \\
\hline 16 & a-Terpineol & $0.87 \pm 0.08$ & - & - & - & \\
\hline \multicolumn{7}{|l|}{ Esters } \\
\hline 17 & Octyl acetate & $0,10 \pm 0.01$ & - & - & $1.91 \pm 0.04$ & $\begin{array}{l}\text { Anti-inflammatory [59] } \\
\text { Analgesic [59] }\end{array}$ \\
\hline \multicolumn{7}{|c|}{ Sesquiterpenes } \\
\hline 18 & $\beta$-Caryophyllene & $0.14 \pm 0.02$ & - & - & - & \\
\hline
\end{tabular}

SD standard deviations

${ }^{a}$ The $\mathrm{w} / \mathrm{w}$ percentages were determined by the internal standard method and referred to the amount of each component contained in $100 \mathrm{~g}$ of essential oil

not detected at $22{ }^{\circ} \mathrm{C}$, and the significant decrease of limonene, and $\alpha$ and $\beta$-pinene. On the contrary, linalool and linalyl acetate were appreciably increased contributing to the composition of the gaseous phase of $\mathrm{BEO}$ at $40{ }^{\circ} \mathrm{C}$ with 27.52 and $10.40 \%$, respectively (Table 4 ).

By comparing the composition of bergamot essential oil with those of the gaseous phase in equilibrium with the liquid phase of $\mathrm{BEO}$ at 0,22 and $40{ }^{\circ} \mathrm{C}$, we observed that seven components of bergamot essential oil (terpinolene, ocimene, neral, gerianal, neryl acetate, $\alpha$-terpineol, $\beta$-cariofyllene) were totally absent in the compositions of all analyzed gaseous phases.

Additionally both in the essential oil and gaseous phase at $40{ }^{\circ} \mathrm{C}$ the major components, albeit with different percentages, are limonene, linalool, $\gamma$-terpinene and linalyl acetate (Table 4). 


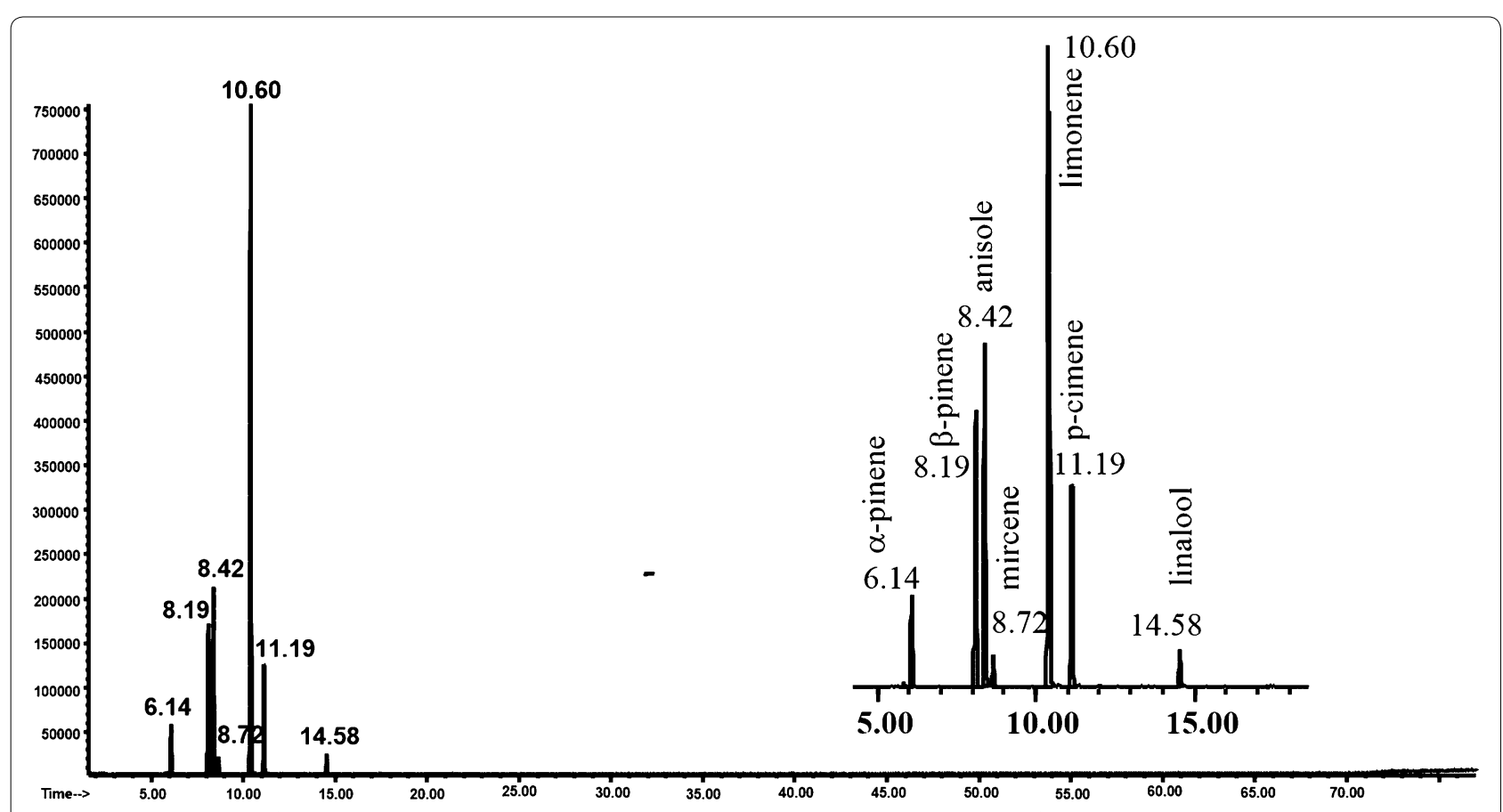

Fig. $1 \mathrm{GC}-\mathrm{MS}$ analysis of the gaseous phase of bergamot essential oil at $0{ }^{\circ} \mathrm{C}$ (a-pinene $t_{R}=6.14 \mathrm{~min} ; \beta$-pinene $t_{R}=8.19$ min; anisole $t_{R}=8.42 \mathrm{~min}$; mircene $t_{R}=8.72 \mathrm{~min}$; limonene $t_{R}=10.60 \mathrm{~min} ; p_{\text {-cimene }} t_{R}=11.19 \mathrm{~min}$; linalool $t_{R}=14.58 \mathrm{~min}$ )

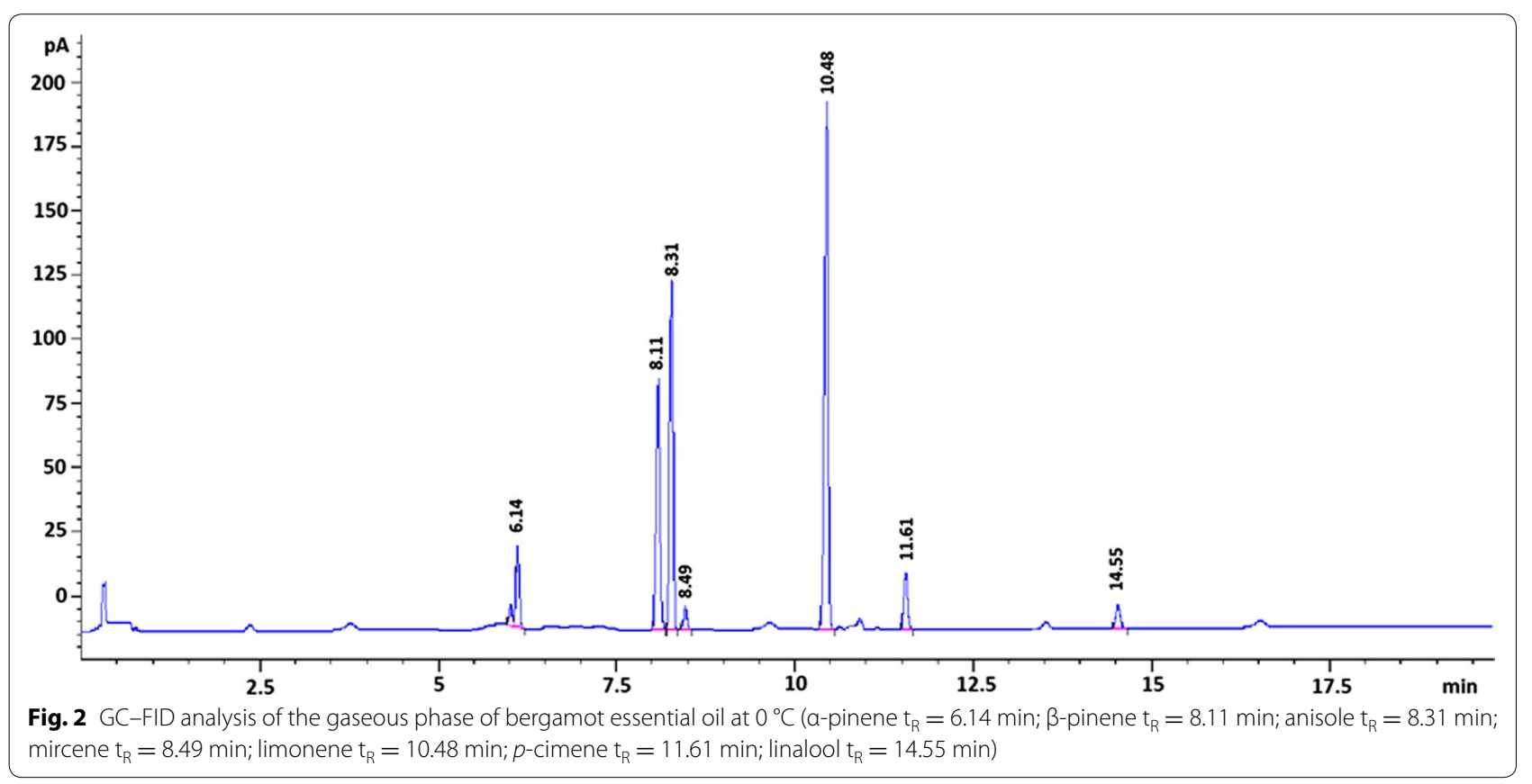

All these results showed that the compositions of the gaseous phases of $\mathrm{BEO}$ generated at various temperatures $\left(0,22\right.$ and $\left.40{ }^{\circ} \mathrm{C}\right)$ are different and change also respect to the composition of the essential oil. Many of the components present in the essential oil are totally absent in the gas phase even at $40{ }^{\circ} \mathrm{C}$ while others, present in small portion in the essential oil, are concentrated in the gaseous phase.

The model we studied represents a closed system that, with some limits, mimics the open system in which 
aromatherapy is usually performed where the gas composition should change until the equilibrium is achieved in the room environment.

Therefore our system could approximate the conditions under which aromatherapy is practiced.

\section{Conclusion}

These results suggest that the determination of the gaseous phase composition in equilibrium with the liquid essential oil is critical for establishing the correlation between the volatile components and their activity.

This study showed that for employing bergamot essential oil in aromatherapy it is not enough to know the essential oil composition but is extremely important to know the volatile fraction composition in equilibrium with it.

This paper reports a GC-MS methodology for the direct analysis of volatile compounds of bergamot essential oil.

The method can also be applied to environments of greater volume provided that the parameters relating to temperature are maintained and that there exist conditions whereby the vapor phase is in equilibrium with the essential oil.

The developed method is quite general and can be applied to other vegetable matrices.

\section{Authors' contributions \\ AL performed research and drafted the manuscript, VL performed the research, ELB, IS and DT analyzed the data results, MLDG and ER participated in writing and editing results, GS and ALiguori proposed the subject and designed the research. All authors read and approved the final manuscript.}

\section{Author details \\ 1 Dipartimento di Farmacia e Scienze della Salute e della Nutrizione, Università della Calabria, Edificio Polifunzionale, 87036 Arcavacata di Rende, CS, Italy. 2 Dipartimento di Chimica e Tecnologie Chimiche, Università della Calabria, 87036 Arcavacata di Rende, CS, Italy.}

\section{Acknowledgements}

Vanessa Leotta thanks Regione Calabria for awarding a fellowship.

\section{Competing interests}

The authors declare that they have no competing interests.

Availability of data and materials

Not applicable.

\section{Consent for publication}

Not applicable.

\section{Ethics approval and consent to participate}

Not applicable.

\section{Funding}

Calabria Region (PSR, Misura 1.2.4, 2013).

\section{Publisher's Note}

Springer Nature remains neutral with regard to jurisdictional claims in published maps and institutional affiliations.
Received: 24 July 2017 Accepted: 19 October 2017

Published online: 02 November 2017

\section{References}

1. Edris AE (2007) Pharmaceutical and therapeutic potentials of essential oils and their individual volatile constituents: a review. Phytother Res 21:308-323

2. Navarra M, Ferlazzo N, Cirmi S, Trapasso E, Bramanti P, Lombardo G, Miciullo PL, Calapai G, Gangemi S (2015) Effects of bergamot essential oil and its extractive fractions on SH-SY5Y human neuroblastoma cell growth. J Pharm Pharmacol 67:1042-1053

3. Calixto JB (2000) Efficacy, safety, quality control, marketing and regulatory guidelines for herbal medicines (phytotherapeutic agents). Braz J Med Biol 33:179-189

4. Howes MJ, Perry NS, Houghton PJ (2003) Plants with traditional uses and activities, relevant to the management of Alzheimer's disease and other cognitive disorders. Phytother Res 17:1-18

5. Van der Watt G, Laugharne J, Janca A (2008) Complementary and alternative medicine in the treatment of anxiety and depression. Curr Opin Psychiatr 21:37-42

6. Buchbauer G, Jirovetz L (1993) Aromatherapie-definition und discussion uber den stand der forschung. Arstezeitschrift fur Naturheilverfahren 34:259-264 (German)

7. Buchbauer $G$, Jirovetz $L$ (1994) Aromatherapy use of fragrance and essential oils as medicament. Flavour Fragr J 9:217-222

8. Buchbauer G, Jirovetz L, Jager W, Plank C, Dietrich H (1993) Fragrance compounds and essential oils with sedative effects upon inhalation. J Pharm Sci 82:660-664

9. Cooke B, Ernst E (2000) Aromatherapy: a systematic review. Br J Gen Pract 50:493-496

10. Vickers A (2000) Why aromatherapy works (even if it doesn't) and why we need less research. Br J Gen Pract 50:444-445

11. Field T, Connie Morrow MS, Chad Valdeon BS, Larson S, Kuhn C, Saul Schanberg MD (1992) Massage reduces anxiety in child and adolescent psychiatric patients. J Am Acad Child Adolesc Psychiatry 31:125-131

12. Diego MA, Jones NA, Field T, Hernandez-Reif M, Schanberg S, Kuhn C, McAdam V, Galamaga R, Galamaga M (1998) Aromatherapy positively affects mood, EEG patterns of alertness and math computations. Int J Neurosci 96:217-224

13. Campenni CE, Crawley EJ, Meier ME (2004) Role of suggestion in odorinducing mood change. Psychol Rep 94:1127-1136

14. Tomi K, Fushiki T, Murakami H, Matsumura Y, Hayashi T, Yazawa S (2011) Relationships between lavender aroma component and aromachology effect. Acta Hortic 925:299-306

15. Herz RS (2009) Aromatherapy facts and fictions: a scientific analysis of olfactory effects on mood, physiology and behavior. Int J Neurosci 119:263-290

16. Lin CY, Chen YH, Chang TC, Chen YJ, Cheng SS, Chang ST (2013) Characteristic aroma-active compounds of floral scent in situ from Barringtonia racemosa and their dynamic emission rates. J Agric Food Chem 61:12531-12538

17. Ndao DH, Ladas EJ, Cheng B, Sands SA, Snyder KT, Garvin JH, Kelly KM (2012) Inhalation aromatherapy in children and adolescents undergoing stem cell infusion: results of a placebo-controlled double-blind trial. Psychooncology 21:247-254

18. Snow NH (2002) Headspace analysis in modern gas chromatography. Trend Anal Chem 21:9-10

19. Popovici J, Bertrand C, Bagnarol E, Fernandez MP, Compte G (2008) Chemical composition of essential oil and headspace-solid microextracts from fruits of Myrica gale L. and antifungal activity. Nat Prod Res 22:1024-1032

20. Tranchida PQ, Presti ML, Costa R, Dugo P, Dugo G, Mondello L (2006) High-throughput analysis of bergamot essential oil by fast solid-phase microextraction-capillary gas chromatography-flame ionization detection. J Chromatogr A 1136:162-165

21. Socaci SA, Tofană M, Socaciu C, Semeniuc C (2009) Optimization of HS/ GC-MS method for the determination of volatile compounds from indigenous rosemary. J Agric Process Technol 15:45-49 
22. Baránková E, Dohnal V (2016) Effect of additive on volatility of aroma compounds from dilute aqueous solutions. Fluid Phase Equilib 407:217-223

23. Di Donna L, De Luca G, Mazzotti F, Napoli A, Salerno R, Taverna D, Sindona G (2009) Statin-like principles of bergamot fruit (Citrus bergamia): isolation of 3-hydroxymethylglutaryl flavonoid glycosides. J Nat Prod 72:1352-1354

24. Leopoldini M, Malaj N, Toscano M, Sindona G, Russo N (2010) On the inhibitor effects of bergamot juice flavonoids binding to the 3-hydroxy3-methylglutaryl-CoA reductase (HMGR) enzyme. J Agric Food Chem 58:10768-10773

25. Di Donna L, Gallucci G, Malaj N, Romano E, Tagarelli A, Sindona G (2011) Recycling of industrial essential oil waste: Brutieridin and Melitidin, two anticholesterolaemic active principles from bergamot albedo. Food Chem 125:438-441

26. Di Donna L, lacopetta D, Cappello AR, Gallucci G, Martello E, Fiorillo M, Dolce V, Sindona G (2014) Hypocholesterolaemic activity of 3-hydroxy3-methyl-glutaryl flavanones enriched fraction from bergamot fruit (Citrus bergamia): "in vivo" studies. J Funct Foods 7:558-568

27. Halcon LL (2002) Aromatherapy: therapeutic applications of plant essential oils. Minn Med 85:42-46

28. Wiebe $\mathrm{E}$ (2000) A randomized trial of aromatherapy to reduce anxiety before abortion. Eff Clin Pract 4:166-169

29. Wilkinson SM, Love SB, Westcombe AM, Gambles MA, Burgess CC, Cargill A (2007) Effectiveness of aromatherapy massage in the management of anxiety and depression in patients with cancer. A multicenter randomized controlled trial. J Clin Oncol 25:532-539

30. Yamaguchi M, Hanawa N, Hamazaki K, Satoc K, Nakanoc K (2007) Evaluation of the acute sedative effect of fragrances based on a biochemical marker. J Essent Oil Res 19:470-476

31. Navarra M, Mannucci C, Delbò M, Calapai G (2015) Citrus bergamia essential oil: from basic research to clinical application. Front Pharmacol 6:1-7

32. Saiyudthong S, Marsden CA (2011) Acute effects of bergamot oil on anxiety-related behaviour and corticosterone level in rats. Phytother Res 25:858-862

33. Fantin G, Fogagnolo M, Maietti S, Rossetti S, Maietti S (2010) Selective removal of monoterpenes from bergamot oil by inclusion in deoxycholic acid. J Agric Food Chem 58:5438-5443

34. Belsito EL, Carbone C, Di Gioia ML, Leggio A, Liguori A, Perri F, Siciliano C, Viscomi MC (2007) Comparison of the volatile constituents in coldpressed bergamot oil and a volatile oil isolated by vacuum distillation. J Agric Food Chem 55:7847-7851

35. Chen W, Liu Y, Li M, Mao J, Zhang L, Huang R, Jin X, Ye L (2015) Anti-tumor effect of a-pinene on human hepatoma cell lines through inducing G2/M cell cycle arrest. J Pharmacol Sci 127:332-338

36. Kim DS, Lee HJ, Jeon YD, Han YH, Kee JY, Kim HJ, Shin HJ, Kang J, Lee BS, Kim SH, Kim SJ, Park SH, Choi BM, Park SJ, Um JY, Hong SH (2015) Alphapinene exhibits anti-inflammatory activity through the suppression of MAPKs and the NF-kB pathway in mouse peritoneal macrophages. Am J Chin Med 43:731-742

37. Guzmán-Gutiérrez SL, Gómez-Cansino R, García-Zebadúa JC, JiménezPérez NC, Reyes-Chilpa RJ (2012) Antidepressant activity of Litsea glaucescens essential oil: identification of $\beta$-pinene and linalool as active principles. Ethnopharmacol 143:673-679

38. Wang W, Li N, Luo M, Zu Y, Efferth T (2012) Antibacterial activity and anticancer activity of Rosmarinus officinalis L. essential oil compared to that of its main components. Molecules 17:2704-2713

39. Lin JJ, Lu KW, Ma YS, Tang NY, Wu PP, Wu CC, Lu HF, Lin JG, Chung JG (2014) Alpha-phellandrene, a natural active monoterpene, influences a murine WEHI-3 leukemia model in vivo by enhancing macrophague phagocytosis and natural killer cell activity. In Vivo 28:583-588

40. Siqueira HS, Neto BS, Sousa DP, Gomes BS, Vieira da Silva F, Cunha FVM, Wanderley CWS, Pinheiro G, Cândido AGF, Wong DVT, Ribeiro RA, LimaJúnior RCP, Oliveira FA (2016) a-Phellandrene, a cyclic monoterpene, attenuates inflammatory response through neutrophil migration inhibition and mast cell degranulation. Life Sci 160:27-33

41. Rudbäck J, Bergström MA, Börje A, Nilsson U, Karlberg AT (2012) a-Terpinene, an antioxidant in tea tree oil, autoxidizes rapidly to skin allergens on air exposure. Chem Res Toxicol 25:713-721
42. Hirota R, Roger NN, Nakamura H, Song HS, Sawamura M, Suganuma N (2010) Anti-inflammatory effects of limonene from yuzu (Citrus junos Tanaka) essential oil on eosinophils. J Food Sci 75:87-92

43. D'Alessio PA, Ostan R, Bisson JF, Schulzke JD, Ursini MV (2013) Oral administration of D-limonene controls inflammation in rat colitis and displays anti-inflammatory properties as diet supplementation in humans. Life Sci 92:1151-1156

44. De Almeida AA, Costa JP, de Carvalho RB, de Sousa DP, de Freitas RM (2012) Evaluation of acute toxicity of a natural compound (+)-limonene epoxide and its anxiolytic-like action. Brain Res 1448:56-62

45. Da Fonseca CO, Simão M, Lins IR, Caetano RO, Futuro D, Quirico-Santos T (2011) Efficacy of monoterpene perillyl alcohol upon survival rate of patients with recurrent glioblastoma. J Cancer Res Clin Oncol 137:287-293

46. Chaudhary SC, Siddiqui MS, Athar M, Alam MS (2012) D-Limonene modulates inflammation, oxidative stress and Ras-ERK pathway to inhibit murine skin tumorigenesis. Hum Exp Toxicol 31:798-811

47. Bonjardim LR, Cunha ES, Guimarães AG, Santana MF, Oliveira MG, Serafini MR, Araújo AA, Antoniolli AR, Cavalcanti SC, Santos MR, Quintans-Júnior LJ (2012) Evaluation of the anti-inflammatory and antinociceptive properties of $p$-cymene in mice. Z Naturforsch C 67:15-21

48. Šegvić Klarić M, Kosalec I, Mastelić J, Piecková E, Pepeljn S (2007) Antifungal activity of thyme (Thymus vulgaris L.) essential oil and thymol against moulds from damp dwellings. Lett Appl Microbiol 44:36-42

49. Asbaghian S, Shafaghat A, Zarea K, Kasimov F, Salimi F (2011) Comparison of volatile constituents, and antioxidant and antibacterial activities of the essential oils of Thymus caucasicus, T. kotschyanus and T. vulgaris. Nat Prod Commun 6:137-140

50. Lorenzetti BB, Souza GE, Sarti SJ, Santos Filho D, Ferreira SH (1991) Myrcene mimics the peripheral analgesic activity of lemongrass tea. J Ethnopharmacol 34:43-48

51. Do Vale TG, Furtado EC, Santos JG Jr, Viana GS (2002) Central effects of citral, myrcene and limonene, constituents of essential oil chemotypes from Lippia alba (Mill.) NE Brown. Phytomedicine 9:709-714

52. Da-Silva VA, de-Freitas JC, Mattos AP, Paiva-Gouvea W, Presgrave OA, Fingola FF, Menezes MA, Paumgartten FJ (1991) Neurobehavioral study of the effect of beta-myrcene on rodents. Braz J Med Biol Res 24:827-831

53. Peana AT, D'Aquila PS, Panin F, Serra G, Pippia P, Moretti MD (2002) Anti-inflammatory activity of linalool and linalyl acetate constituents of essential oils. Phytomedicine 9:721-726

54. Peana AT, D'Aquila PS, Chessa ML, Moretti MD, Serra G, Pippia P (2010) $(-)$-Linalool produces antinociception in two experimental models of pain. Nat Prod Commun 5:1847-1851

55. de Sousa DP, Nóbrega FF, Santos CC, de Almeida RN (2010) Anticonvulsant activity of the linalool enantiomers and racemate: investigation of chiral influence. Nat Prod Commun 5:1847-1851

56. Cheng BH, Sheen LY, Chang ST (2014) Evaluation of anxiolytic potency of essential oil and S-(+)-linalool from Cinnamomum osmophloeum ct. linalool leaves in mice. J Tradit Complement Med 5:27-34

57. Da Silva LG, Luft C, Lunardelli A, Amaral RH, Da Silva Melo DA, Donadio MVF, Nunes FB, De Azambuja MS, Santana JC, Moraes CMB, Mello RO, Cassel E, De Almeida Pereira MC, De Oliveira JR (2015) Antioxidant, analgesic and anti-inflammatory effects of lavender essential oil. An Acad Bras Cienc 87:1397-1408

58. Trombetta D, Castelli F, Sarpietro MG, Venuti V, Cristani M, Daniele C, Saija A, Mazzanti G, Bisignano G (2005) Mechanisms of antibacterial action of three monoterpenes. Antimicrob Agents Chemother 49:2474-2478

59. Hajhashemi V, Sajjadi SE, Heshmati M (2009) Anti-inflammatory and analgesic properties of Heracleum persicum essential oil and hydroalcoholic extract in animal models. J Ethnopharmacol 124:475-480 